\title{
Superficial temporal artery haemorrhage caused by neurophysiological monitoring: a unique MRI finding
}

\section{Geoffrey W Peitz, ${ }^{1}$ Wylan C Peterson, ${ }^{2}$ Shaheryar Hafeez, ${ }^{1}$ Ramesh Grandhi ${ }^{1}$}

Department of Neurosurgery, University of Texas Health Science Center at San Antonio, San Antonio, Texas, USA ${ }^{2}$ Department of Surgery, San Antonio Military Medical Center, Fort Sam Houston, Texas, USA

\section{Correspondence to} Ramesh Grandhi, grandhi@uthscsa.edu

Accepted 27 December 2016 CrossMark

\section{To cite: Peitz GW} Peterson WC, Hafeez $S$, et al. BMJ Case Rep Published online: [please include Day Month Year] doi:10.1136/bcr-2016218557

\section{DESCRIPTION}

A woman aged 66 years with a history of diplopia, headaches and left Cranial Nerve 3 palsy was found to have a $2 \mathrm{~cm}$ left paraclinoid internal carotid artery aneurysm. She was started on aspirin and clopidogrel and underwent flow diversion treatment with Pipeline (Covidien Neurovascular, Irvine, California, USA) embolisation of the aneurysm. Intraoperative neurophysiological monitoring via EEG and somatosensory evoked potentials was performed. After the procedure, she was found to have a large right scalp haematoma extending to the right orbit anteriorly and the back of the head posteriorly. Despite manual compression, the periorbital swelling continued to increase in the intensive care unit such that she was not able to open the right eye. A routine postprocedural MRI and MRA of the brain with gadolinium was performed to assess the aneurysm; of note, the study also demonstrated a large right scalp haematoma with contrast enhancement around the superficial temporal artery (STA) consistent with extravasation (figures 1 and 2). A delayed sequence was not performed to distinguish between the pseudoaneurysm and active haemorrhage, but given the enlargement of the haematoma before and after the MRI, active

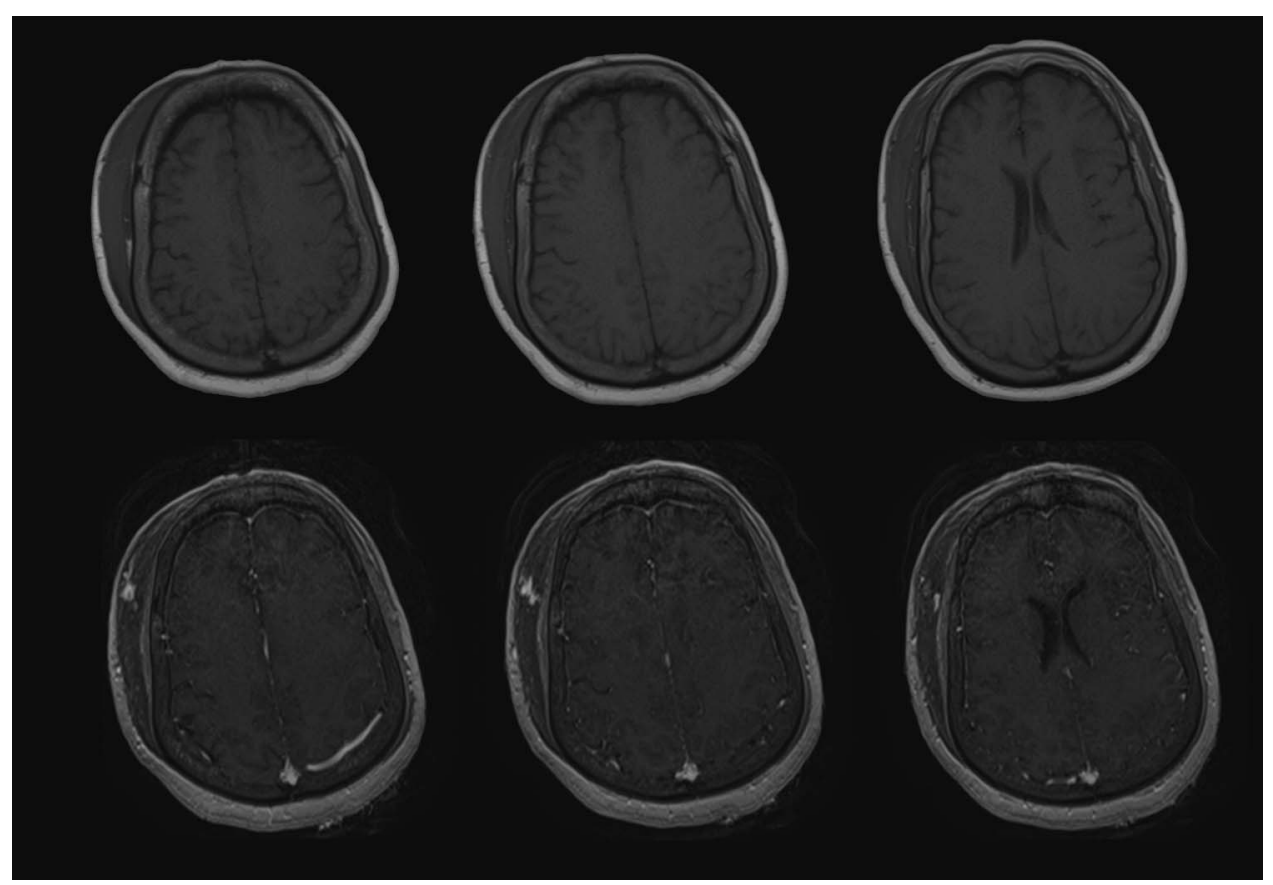

Figure 1 Axial, T1-weighted, precontrast (top row) and postcontrast (bottom row) images progressing from superior (left) to inferior (right) demonstrate contrast enhancement within a right scalp haematoma.

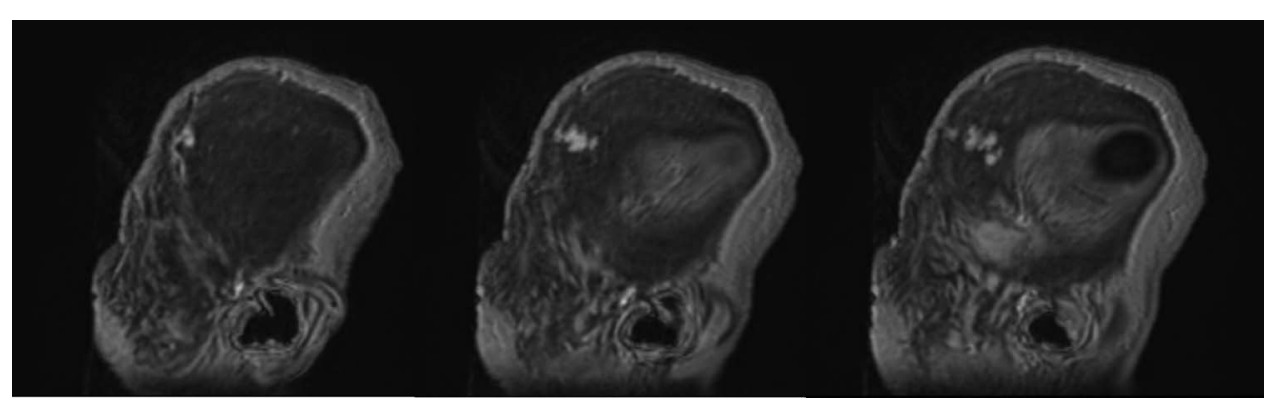

Figure 2 Sagittal, postcontrast, T1-weighted images progressing from lateral (left) to medial (right) show contrast enhancement arising at the right superficial temporal artery and extending posteriorly and inferiorly within the right scalp hematoma. 


\section{Learning points}

Arterial injury is a potential complication of neurophysiological monitoring which can have especially deleterious consequence in patients taking antiplatelet agents.

- Compression and local, transdermal epinephrine is a treatment strategy for controlling superficial temporal artery haemorrhage in patients who continue with antiplatelet agents to prevent stent thrombosis. on adverse events caused by neurophysiological monitoring are limited. Haemorrhagic complications in patients taking antiplatelet agents following Pipeline embolisation procedures have been documented, ${ }^{2}$ but STA haemorrhage from scalp electrode insertion has not been reported.

Contributors GWP performed the literature review, drafted the manuscript and selected images. RG saw the patient in clinic, performed the patient's procedure and edited the manuscript and figures. WCP and SH treated the patient's haematoma in the intensive care unit and contributed to and edited the manuscript.

Competing interests None declared.

Patient consent Obtained.

Provenance and peer review Not commissioned; externally peer reviewed.

\section{REFERENCES}

1 Chen L, Spetzler RF, McDougall CG, et al. Detection of ischemia in endovascular therapy of cerebral aneurysms: a perspective in the era of neurophysiological monitoring. Neurosurg Rev 2011;34:69-75.

2 Skukalek SL, Winkler AM, Kang J, et al. Effect of antiplatelet therapy and platelet function testing on hemorrhagic and thrombotic complications in patients with cerebral aneurysms treated with the pipeline embolization device: a review and meta-analysis. J Neurointerv Surg 2016;8:58-65.

Copyright 2017 BMJ Publishing Group. All rights reserved. For permission to reuse any of this content visit http://group.bmj.com/group/rights-licensing/permissions.

BMJ Case Report Fellows may re-use this article for personal use and teaching without any further permission.

Become a Fellow of BMJ Case Reports today and you can:

- Submit as many cases as you like

- Enjoy fast sympathetic peer review and rapid publication of accepted articles

- Access all the published articles

- Re-use any of the published material for personal use and teaching without further permission

For information on Institutional Fellowships contact consortiasales@bmjgroup.com

Visit casereports.bmj.com for more articles like this and to become a Fellow 